\title{
Tree-Ring Reconstruction of Debris-Flow Events Leading to Overbank Sedimentation on the Illgraben Cone (Valais Alps, Switzerland)
}

\author{
Markus Stoffel ${ }^{*}, \mathrm{a}, \mathrm{b}$, Michelle Bollschweiler $^{\mathrm{a}}$, Astrid Leutwiler ${ }^{\mathrm{a}, \mathrm{c}}$ and Patrick Aeby ${ }^{\mathrm{a}}$ \\ ${ }^{a}$ Dendrolab.ch, Laboratory of Dendrogeomorphology, Department of Geosciences, University of Fribourg, 1700 \\ Fribourg, Switzerland \\ ${ }^{b}$ Climate Change and Climate Impacts $\left(C^{3} i\right)$, University of Geneva, 1227 Carouge-Geneva, Switzerland \\ ${ }^{c}$ Swiss Federal Office for the Environment (FOEN), Worblentalstrasse 68, 3063 Ittigen-Berne, Switzerland
}

\begin{abstract}
Dendrogeomorphological analyses of trees affected by debris flows have regularly been used to date past events. However, while previous studies in the Swiss Alps have focused primarily on granitic and gneissic debris-flow material and on Larix decidua Mill. and Picea abies (L.) Karst. trees, they have - at the same time - widely disregarded torrents dominated by finely fractured calcareous and dolomitic lithologies and forests populated with Pinus sylvestris L. In this paper, we report on results obtained from a debris-flow cone in the Rhone valley (Valais, Switzerland) where very fine and muddy material (limestone, dolomite, quartzite and calcite) occasionally affects $P$. sylvestris trees. Based on the results of a geomorphic map, 1004 increment cores from 451 disturbed $P$. sylvestris, $37 \mathrm{~L}$. decidua and five $P$. abies trees were sampled, allowing reconstruction of 15 events between AD 1793 and 2005 as well as the determination of breakout locations of events. From the data, it also appears that debris-flow material only rarely left the incised channel over the last 200 years and that overbank sedimentation events did not occur after 1961, when a rockslide delivered large amounts of erodible material and subsequent debris flows caused an important incision of the canyon on the cone.
\end{abstract}

Keywords: Debris flow, tree-ring analysis, dendrogeomorphology, overbank sedimentation, Pinus sylvestris L., Swiss Alps.

\section{INTRODUCTION}

Debris flows are among the most common and widespread geomorphic processes in mountain regions, where their repeated occurrence may result in characteristic landforms with cones, channels and lo-bate deposits. In inhabited areas, they may cause damage to transportation corridors and buildings or even lead to the loss of lives $[1,2]$. As a consequen-ce, the understanding of the process as well as the behavior of debris-flow events in space and time is crucial for the mitigation of related hazards and risks [3-5].

For most torrents in the Swiss Alps, however, systematic acquisition of data on previous debris flows only started after several catastrophic events, namely in 1987, 1993, 2000 or 2005 [6-9]. Additional information on past events is rare and archival data, at best, very fragmentary. The reconstruction and appraisal of past activity therefore seems essential for the understanding of current debris-flow dynamics in mountain torrents as well as possible future evolutions.

The most accurate technique to date events over several centuries in the past is dendrogeomorphology [10]. The method is based on the fact that trees growing in temperate climates form annual growth rings and that they record external disturbances such as climatic fluctuations or geomorphic process activity in their tree-ring series [11-14]. Given that a tree is directly impacted by a debris flow, tree-ring

*Address correspondence to this author at the Dendrolab.ch, Laboratory of Dendrogeomorphology, Department of Geosciences, University of Fribourg, 1700 Fribourg, Switzerland; E-mail: markus.stoffel@unifr.ch dating can pinpoint the year or sometimes even the season in which the disturbance occurred. Previous dendrogeomorphological studies primarily focused on (i) the reconstruction of magnitudes and/or frequencies [15-17], (ii) spatial patterns of past debris flows on forested cones [18, 19], (iii) recolonization of cones with trees following large and devastating events [20] or (iv) the comparison of reconstructed debris-flow data with archival records on flooding in neighboring rivers [21]. Tree-ring evidence was also used to (v) assess changes in the seasonality of debris-flow activity and to (vi) identify possible impacts of a future greenhouse climate on the frequency or magnitude of events $[19,22]$.

While previous studies in the Swiss Alps extensively focused on cones that are regularly affected by debris-flow events transporting blocky crystalline material (i.e. gneiss or granite), they have, at the same time, completely disregarded (i) the investigation of activity in regions dominated by finely fractured calcareous and dolomitic lithologies or (ii) the analysis of exceptional debris-flow events in canyons leading to overbank sedimentation on cones. In a similar way and due to their sensitivity towards drought stress [23, 24], (iii) tree-ring series of Scots pine (Pinus sylvestris L.) have only very rarely been used for dendrogeomorphological investigations in Switzerland so far.

It is therefore the aim of this study to reconstruct past overbank sedimentation events from the deeply incised debris-flow canyon of the Illgraben torrent. Through the identification of surface deposits and the analysis of 1004 ringwidth series obtained from 451 Scots pine (Pinus sylvestris L.), 37 European larch (Larix decidua Mill.) and five Norway spruce (Picea abies (L.) Karst.) trees, we (i) investigate 


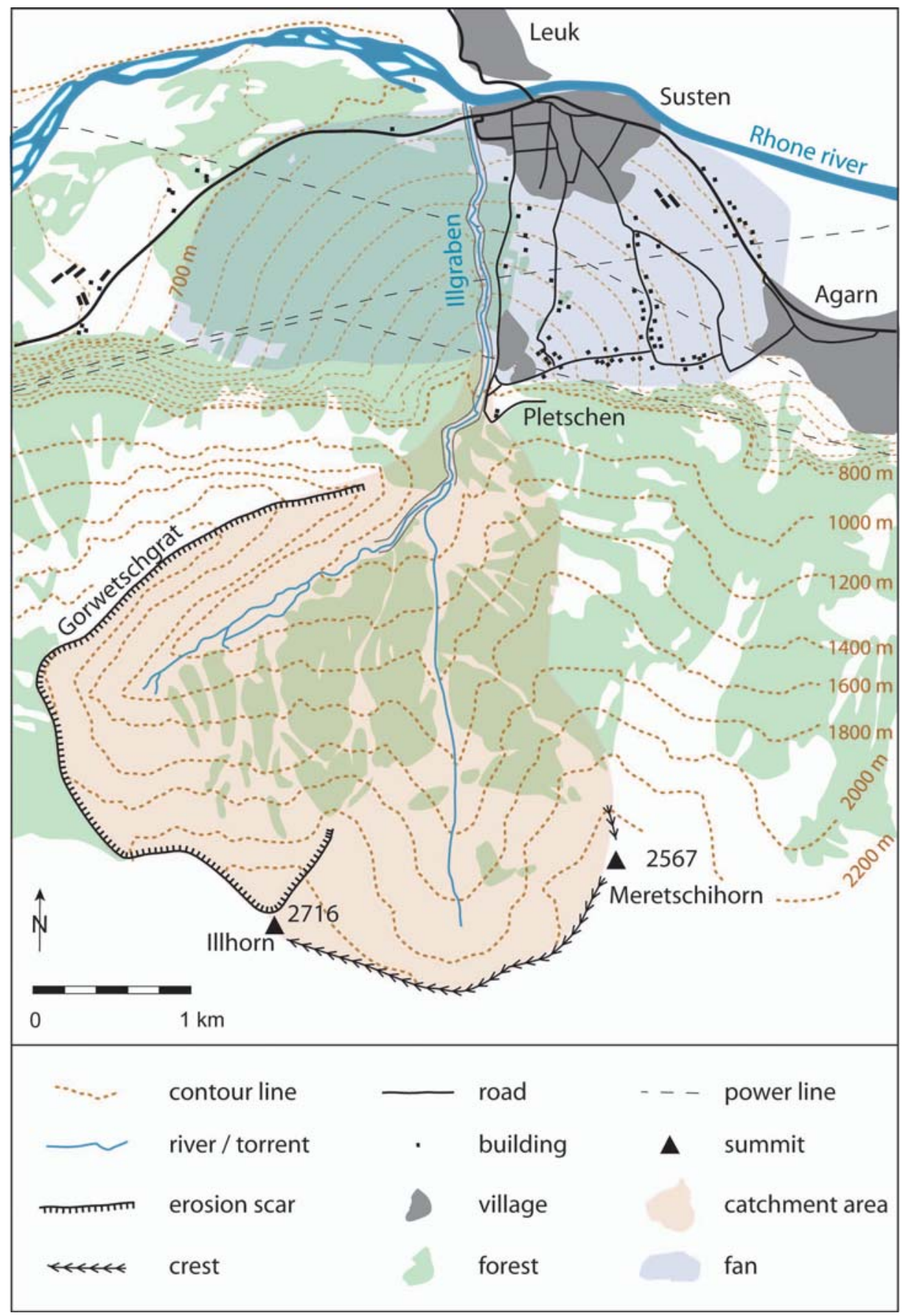

Fig. (1). Illustration of the Illgraben catchment area (ocher) and its debris-flow fan (blue) located in the Rhone valley (Valais, Switzerland).

the effect of very slurry and muddy debris-flow material on tree growth, (ii) analyze the sensitivity and utility of $P$. sylvestris for dendrogeomorphological analyses, (iii) reconstruct the history of overbank sedimentation incidences, (iv) analyze recent debris-flow activity on the low terraces inside the canyon, before we (v) discuss the effects of changes in geomorphic conditions upon the occurrence of future overbank sedimentation events.

\section{STUDY SITE}

The area investigated in this study is the Illgraben, a mountain torrent located in the central part of the Rhone valley (Valais, Swiss Alps, $46^{\circ} 18^{\prime} \mathrm{N} / 7^{\circ} 38^{\prime} \mathrm{E}$; Figs. (1 and 2A)). The catchment area of the Illgraben covers $10.5 \mathrm{~km}^{2}$.
The primary channel has a length of $\sim 3 \mathrm{~km}$, two thirds of the channel are located on the cone, where the torrent meanders in a deeply incised canyon (Fig. 2B). Present-day incision depths on the cone range from 3 to $\geq 25 \mathrm{~m}$.

Between the cone apex ( $880 \mathrm{~m}$ a.s.1.) and the confluence of the torrent with the Rhone river $(610 \mathrm{~m}$ a.s.1.), the mean slope angle averages only $10.2^{\circ}\left(\max .11 .1^{\circ}, \min .8 .4^{\circ}\right)$. As a result of this very low gradient, the Illgraben torrent has formed one of the largest cones of the European Alps during the Holocene with a radius of $2 \mathrm{~km}$, a surface of $6.6 \mathrm{~km}^{2}$ and an estimated volume of $0.7-0.9 \mathrm{~km}^{3}$ [25].

Mean annual precipitation ranges from $\sim 570 \mathrm{~mm}$ in the lower part of the drainage basin [26] to $1700 \mathrm{~mm}$ at its sum- 

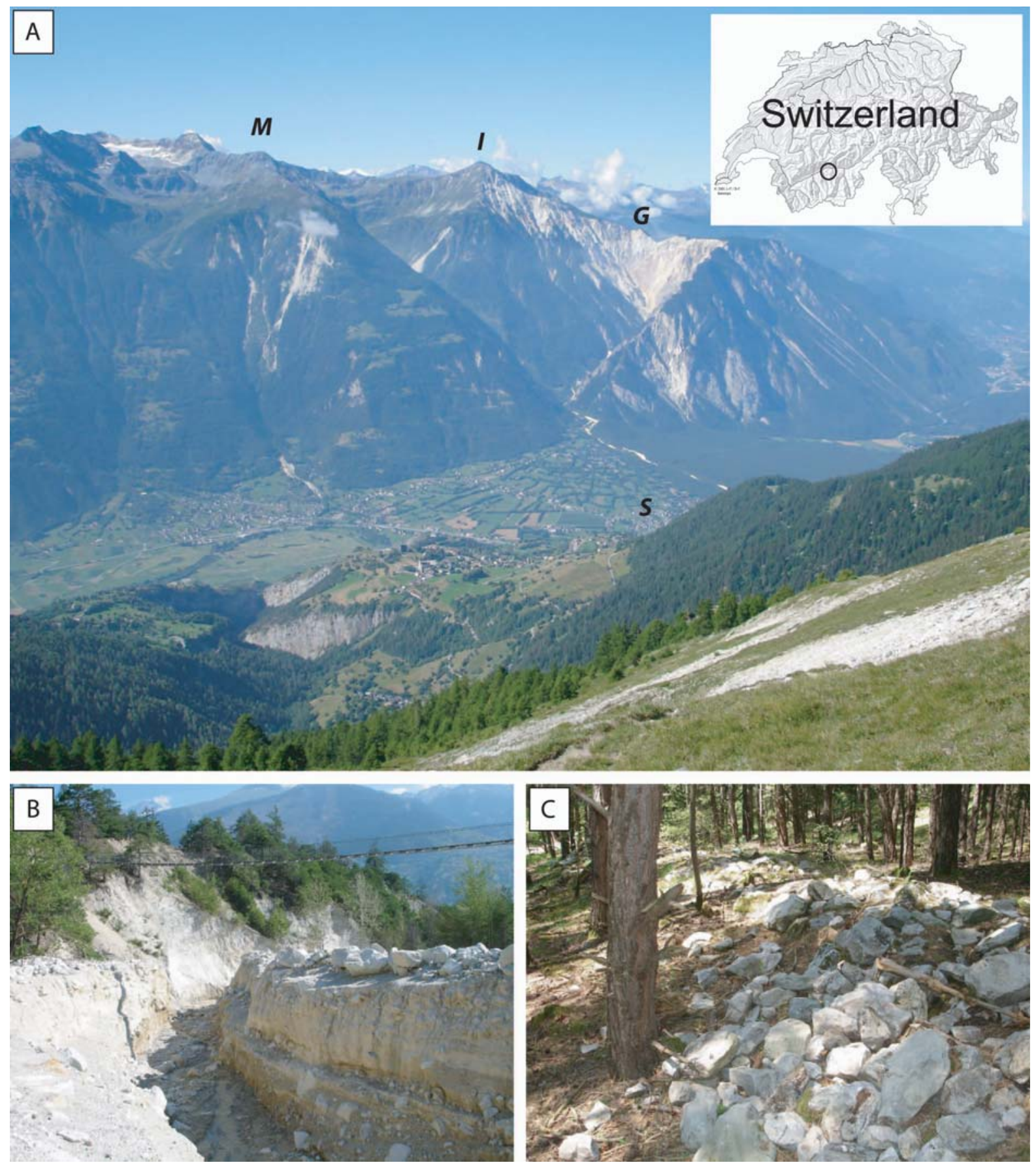

Fig. (2). (A) Overview of the Illgraben basin with the catchment located between the Gorwetschgrat $(G)$, Illhorn $(I)$ and Meretschihorn $(M)$ and the debris-flow fan with the village of Susten $(S)$; (B) The Illgraben torrent is deeply incised on the cone and the canyon reaches depths of up to $25 \mathrm{~m}$; (C) Deposits of former debris-flow activity are scarce and levees are only identified occasionally on the present-day cone surface.

mits [27], rendering it one of the driest sites in Switzerland [28]. Intense rainstorms occur mainly in summer, and estimated rainfall intensities with a return period of 100 years are 35 and $57 \mathrm{~mm} \mathrm{~h}^{-1}$ for a 0.5 and a $1 \mathrm{~h}$ rainfall event, respectively [27].

Vegetation inside the canyon is regularly removed by debris flows and primarily consists of young broadleaved species (Alnus sp., Betula sp., Populus sp., Salix sp., Sambucus nigra L.). Outside the canyon, the largest Scots pine forest (Pinus sylvestris L.) of the Alps predominates the western part of the cone [29], European larch (Larix decidua Mill.) and Norway spruce (Picea abies (L.) Karst.) are scarce in this dry environment. The eastern part is, in contrast, extensively used as agricultural land close to the cone apex, whereas the settlements of Susten and Pletschen occupy the lower reaches of the cone.

Debris-flow material originates from a huge and asymmetric erosion corrie between the Illhorn and the Gorwetschgrat (Fig. 2A). The south-east to north-east facing rock walls between the Gorwetschgrat and the Illhorn $(2,716$ 
$\mathrm{m}$ a.s.1.) have mean slope angles varying between 40 and $50^{\circ}$ and are built of heavily disintegrated calcite, dolomite and greywacke layers of Permian and Triassic age [30]. While the dolomitic and parts of the Triassic layers primarily produce very fine sediments (silts), rockslides are regularly triggered from the more compact calcite layers. The last big rockslide event occurred on 26 March 1961, when $\sim 5 \times 10^{6}$ $\mathrm{m}^{3}$ of rocks have been released and deposited in the upper debris-flow channel [25]. East of the Illhorn, quartzite layers predominate and current-day geomorphic processes are less predominant. In the channel bed of the Illgraben - located at 1200 to $900 \mathrm{~m}$ a.s.1. - geology consists of gneiss and schist layers.

The deposition of the loose and highly erosive material by the 1961 rockslide has led to at least 21 debris-flow events between the rockslide in March 1961 and July 1965 , with several of the surges transporting more than $250^{\prime} 000 \mathrm{~m}^{3}$ each [25]. As a consequence, a $\sim 50 \mathrm{~m}$ high retention dam has been built in the departure zone as well as 21 check dams constructed in the canyon on the cone between 1967 and 1969 so as to retain the rockslide deposits in the middle reaches of the torrent and to prevent the release of large debris flows [31]. By the early 1980s, however, the retention dam was completely filled and could no longer prevent the release of new debris flows in the Illgraben torrent [32].

Present-day debris-flow activity is systematically recorded with geophones, radar, laser, and ultrasonic depthmeasuring devices, video cameras, three rain gauges and a debris-flow force plate [33]. Since the installation of the devices in early 2000 and until October 2007, 30 debris-flow events were recorded and data on different debris-flow parameters obtained. Several large events transported close to $100 ' 000 \mathrm{~m}^{3}$, flow velocities varied between 1.1 and $6.3 \mathrm{~m} \mathrm{~s}^{-1}$ and $\mathrm{Q}_{\max }$ attained between 5 and $114 \mathrm{~m}^{3} \mathrm{~s}^{-1}$ [34; pers. comm. Ch. Graf, 2007].

\section{MATERIAL AND METHODS}

\section{Geomorphological Mapping of Debris-Flow Channels and Deposits}

Analysis of past debris-flow activity started with the mapping of all features associated with past activity on both sides of the present-day canyon, such as lobes, levees or abandoned flow paths. Features and deposits originating from other geomorphic processes or anthropogenic activity were indicated on the map as well, so as to avoid misdating of debris-flow events. Due to the presence of a relatively dense forest cover, GPS devices could not be used on the cone, which is why geomorphic mapping was executed with a tape, inclinometer and compass.

\section{Sampling Design}

On both sides of the canyon and on parts of the western half of the debris-flow cone, $P$. sylvestris, L. decidua and $P$. abies trees show visible growth disturbances (GD) related to past debris-flow activity (i.e. tilted stems, partial burying of the trunk, destruction of root mass, erosion, scars). Based on the geomorphic map and on an outer inspection of the stem surface, trees with morphological growth defects due to past debris flows were sampled [10].
In this investigation, at least two cores were extracted per tree using increment borers, one in the flow direction of past debris flows and the other on the opposite side of the trunk (max. size of cores: $40 \mathrm{~cm}$ by $6 \mathrm{~mm}$ ). In order to gather the greatest amount of information on GD caused by past events, increment cores were preferably sampled at the height of the visible damage or within the segment of the stem tilted during past events. In the case of visible scars, further increment cores were extracted from the wound and the overgrowing callus tissue [10]. In total, 493 trees were sampled (451 Pinus sylvestris L., 37 Larix decidua Mill. and five Picea abies (L.) Karst.) with a total of 1004 increment cores on the cone.

Data recorded for each tree sampled included: (i) determination of its position within levees, flow channels or on deposits; (ii) sketches and position of visible disturbances in the tree morphology such as tilted stems, partial burying of the stem, destruction of root mass or erosion as well as scars; (iii) position of the sampled cores on the stem surface; (iv) diameter at breast height $(\mathrm{DBH})$; as well as (v) data on neighboring trees and signs of anthropogenic activity.

\section{Dating of Events and Debris-Flow Frequency}

Samples were analyzed and data processed following the standard procedures described in [10]. Single steps of sample analysis included surface preparation, counting of tree rings, skeleton plots as well as ring-width measurements using digital LINTAB positioning tables connected to a Leica stereomicroscope and TSAP 3.0 (Time Series Analysis and Presentation) software [35]. Growth curves of the disturbed samples were then compared with precipitation records from the Swiss Meteorological Institute [26] and results from dendroecological studies $[23,24,36]$ to separate climatically driven fluctuations (e.g., droughts, frost) in tree growth from GD caused by debris flows [37].

Growth curves were then used to determine the initiation of abrupt growth reduction or recovery [38, 39]. In the case of tilted stems, both the appearance of the cells (i.e. structure of the reaction wood cells) and the growth curve data were analyzed [e.g., 40, 41]. Finally, the cores were visually inspected so as to identify further signs of past debris-flow activity in the form of callus tissue overgrowing abrasion scars [42-44].

Except for the few L. decidua and P. abies trees that were sampled on the cone, resin ducts could not be used for the reconstruction of previous debris-flow events in the present case, as they do not form in tangential series in $P$. sylvestris $[45,46]$. Fig. (3) provides an overview on the different growth features used for the dating of previous debris-flow activity on the cone of the Illgraben torrent.

\section{RESULTS}

\section{Geomorphological Mapping of Debris-Flow Channels and Deposits}

Geomorphic mapping permitted identification of abandoned channels, levees, lobate deposits, and recent fluvial terraces relating to past debris-flow activity on both sides of the Illgraben torrent. Fig. (4) illustrates the features identified on the cone and provides indications of the location of debris-flow retention dams. 


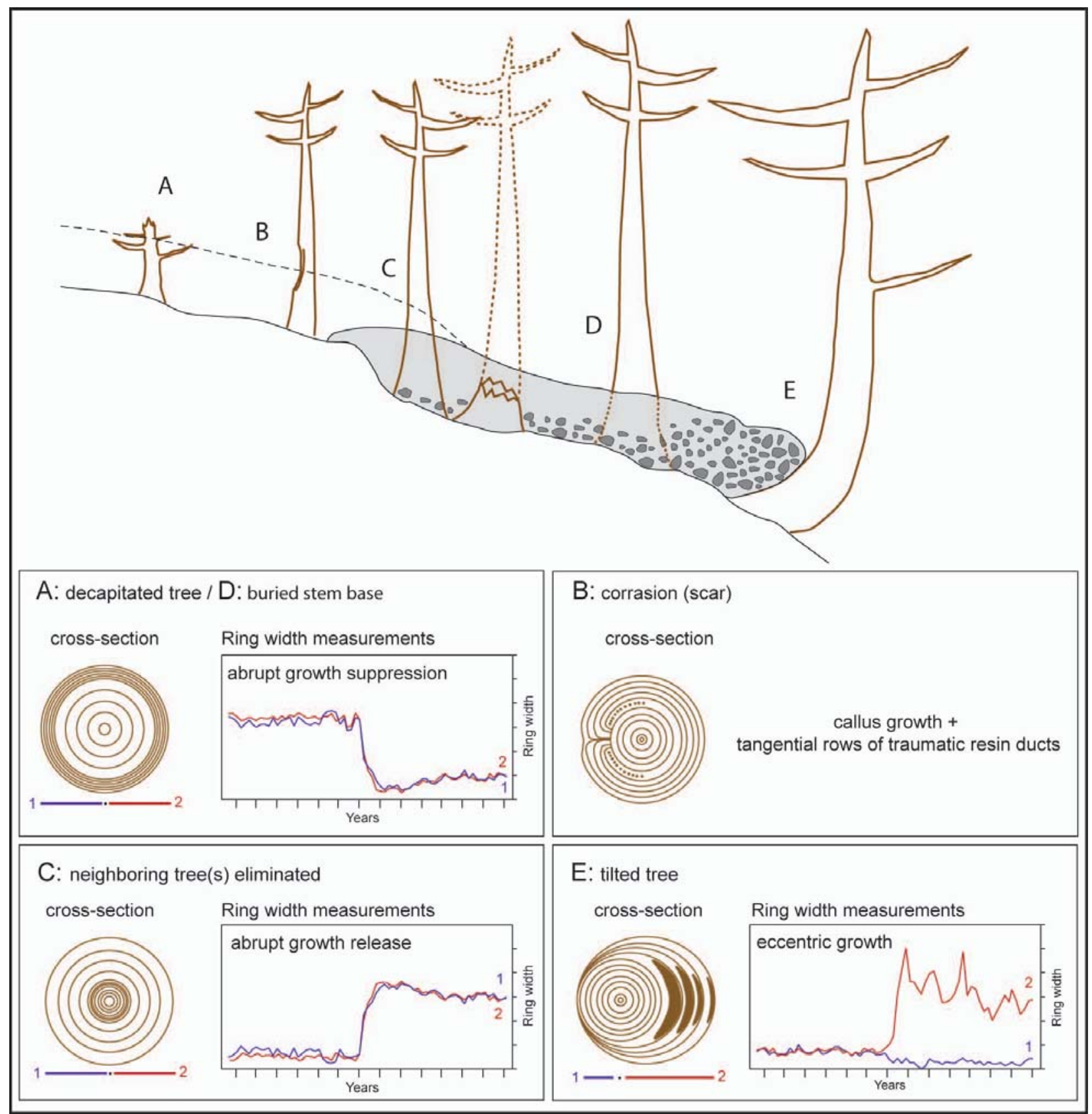

Fig. (3). Growth disturbances of trees affected by a debris-flow event (modified after [17, 42]).

Except for the terraces and a very limited number of lobate deposits or levees (Fig. 2C), geomorphic forms related to past debris-flow activity are comparably scarce on the present-day surface of the Illgraben cone. It appears that material was - as a result of the particular mineralogical composition, granulometry and water content of individual surges - deposited in centimetric to decimetric layers over considerable surfaces of the cone rather than in the form of "typical" lobes or levees.

In addition to the deposits, we observe one abandoned channel separating from the currently active canyon at $\sim 710$ $\mathrm{m}$ a.s.l. being present over most of the lower western part of the cone. The width and depth of the channel vary largely, but - at least for its lower parts (650 to $620 \mathrm{~m}$ a.s.1.) - its dimensions are comparable with those of the present-day canyon.

Profiles of the currently active canyon are given in Fig. (4) for four characteristic locations and their environs (i.e. profiles A to D). Profile A - A' illustrates the situation as shown on Fig. (2B). It indicates that the torrent runs through the deeply incised canyon. While overbank sedimentation appears unlikely under current conditions in this sector, larger surges may lead to shifts of the channel inside the canyon and affect trees growing on the lower terrace.

The canyon is much less incised at the height of profile B - B' and a considerable amount of lobes and levees identified on both terraces testify from past overbank sedimentation events. Profile $\mathrm{C}-\mathrm{C}^{\prime}$ is located directly below the 

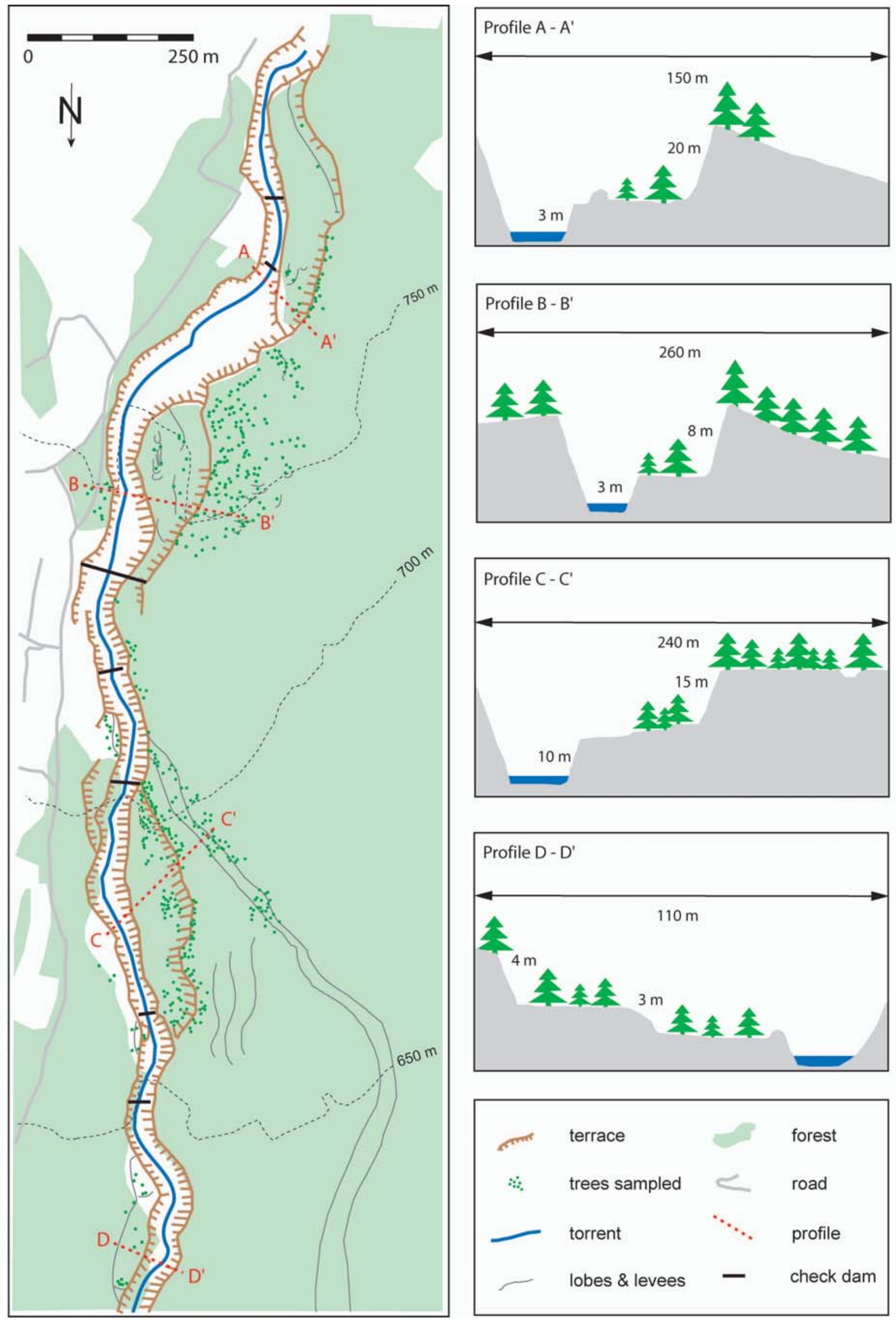

Fig. (4). (left) Geomorphic map of the Illgraben canyon and its cone with lobes and levees indicated in grey. The figure also illustrates the check dams constructed in the late 1960s (black lines) and gives the location of trees (green dots) sampled for analysis. (right) Profiles of the Illgraben canyon at four characteristic locations on the cone. 
bifurcation of the abandoned from the currently active canyon. Geomorphic forms are present on the terrace and on both sides of the old channel. Finally, profile D - D' illustrates the situation of the debris-flow terraces on the right hand side of the channel at approximately $630 \mathrm{~m}$ a.s.1. We observe at least two generations of terraces as well as a few levees and small lobate deposits here.

\section{Tree Age and Growth Disturbances in Trees}

The average age of the $1004 \mathrm{~L}$. decidua, P. abies and $P$. sylvestris trees sampled on the cone is 122.4 years. The oldest tree cored shows 254 tree rings at sampling height (AD 1753), whereas the youngest tree reached breast height only in AD 1975. Although the age structure of the trees selected for analysis is quite heterogeneous, there is a concentration of younger trees in the zone close to the active channel on the eastern side of the cone, where most trees reached sampling height in the (early) $20^{\text {th }}$ century. The oldest trees are located close to the abandoned canyon as well on the western terrace illustrated in profile $\mathrm{A}-\mathrm{A}^{\prime}$.

Table 1. Overview of the Different Growth Disturbances (GD) Assessed in the 1004 Pinus sylvestris L., Larix decidua Mill. and Picea abies (L.) Karst. samples (TRD = Tangential Rows of Traumatic Resin Ducts)

\begin{tabular}{|c|c|c|}
\hline Growth Disturbances (GD) & Abs. Number & $\%$ \\
\hline Growth suppression & 1786 & 76 \\
\hline Growth release & 358 & 15 \\
\hline Compression wood & 168 & 7 \\
\hline TRD & 39 & 2 \\
\hline Callus tissue & 12 & 1 \\
\hline Total & 2363 & 100 \\
\hline
\end{tabular}

Analysis of the disturbed trees allowed reconstruction of 2363 GD caused by passing debris-flow surges or the deposition of material on the cone. Table 1 shows that signatures of past events were mainly identified on the increment cores via abrupt growth suppression (76\%) or recovery (15\%). While reaction wood $(7 \%)$ was occasionally found in the tree-ring records, tangential rows of traumatic resin ducts $(2 \%)$ and callus tissue $(1 \%)$ bordering wounds were only rarely observed on the cores.

\section{Dating Overbank Sedimentation Events}

In total, analysis of GD occurring simultaneously in different trees allowed reconstruction of 30 years with a clustering of anomalous growth reactions in the selected trees between AD 1793 and 2007.

Based on the number of reactions, the nature of GD, the spatial distribution of disturbed trees on the cone as well as on a comparison of our data with results of dendroecological studies and precipitation records, the 30 years with a clustering of GD have been separated into certain and possible debris-flow event years. As a consequence, only 15 years have been defined certain debris-flow event years, as we observe not only abrupt changes in growth in the tree-ring records, but also evidence for injuries or compression wood as a consequence of debris-flow activity. In addition, the spatial distribution of trees with GD appears very sound for these 15 years. Fig. (5) illustrates the reconstructed frequency of these certain debris-flow events that have left the active canyon of the Illgraben torrent and caused overbank sedimentation on the cone during the last 220 years. It also appears from Fig. (5) that - due to the scarcity of old trees - only a limited number of events would have left the canyon in the $18^{\text {th }}$ and $19^{\text {th }}$ century and that one period with repeated overbank sedimentation on the cone would have occurred in the 1950s.

For the other 15 years, the number of anomalous growth reactions was either too small, the GD mostly in the form of abrupt growth suppression and the spatial distribution of trees with disturbances rather dispersed. As a result, these years have only been considered possible events (1801, $1879,1902,1918,1929,1938,1985,1986)$ and it appears feasible that debris flows would have affected the cone during these years as well.

In addition, several years with a considerable number of growth suppression coincide with regional drought years

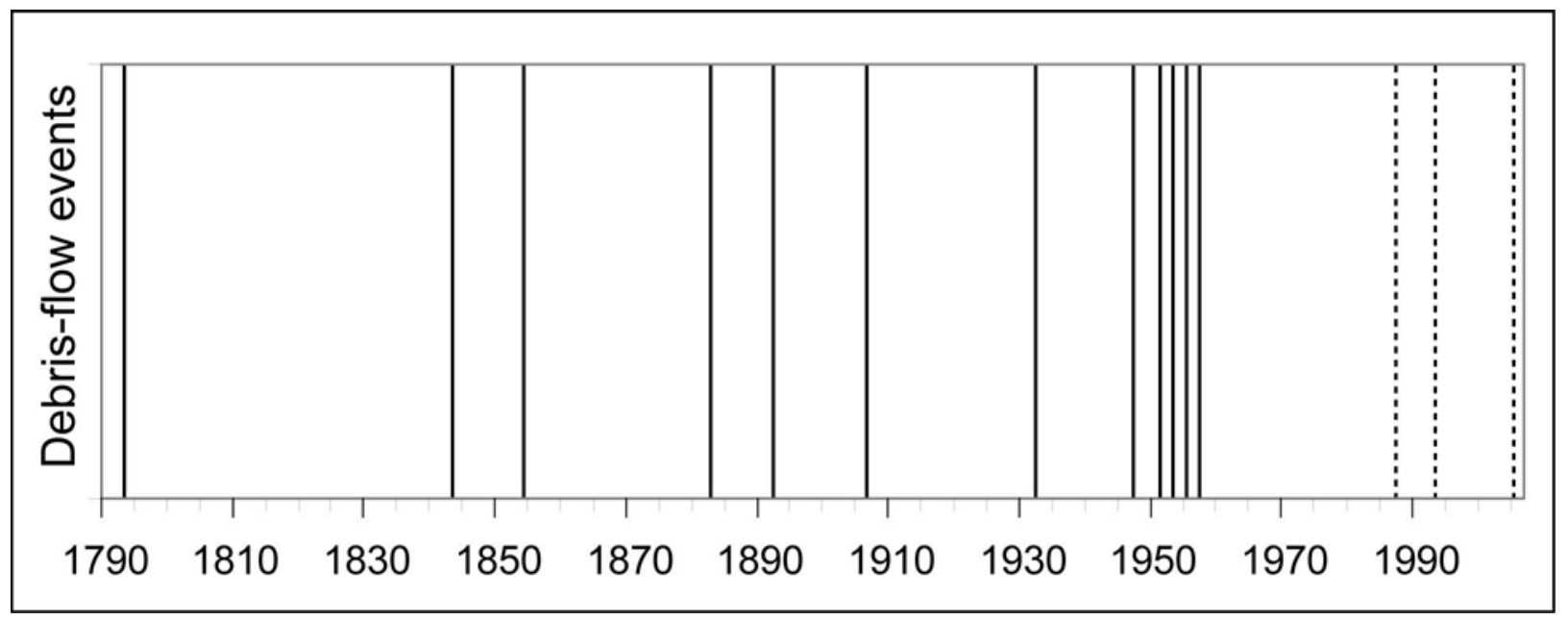

Fig. (5). Reconstructed frequency of outbreaks of debris flows from the Illgraben canyon and subsequent overbank sedimentation on the cone (1793-2007). Solid lines indicate overbank sedimentation events on the cone, dashed lines represent debris flows affecting the terraces inside the canyon. 
$(1920,1933,1941,1943,1946,1971,1989)$. As both geomorphic activity (i.e. burial of the stem base, root exposure and apex decapitation) and climate may result in sudden growth suppression, we did not keep these years for further analysis.

\section{Breakout Locations and Minimum Extent of Overbank Sedimentation Events}

The breakout locations and the minimum spatial extent of past overbank sedimentation events were assessed through the analysis of the position of all trees showing GD in a specific year. In general, events were much more frequently observed on the western part of the cone. In the eastern part, trees were less readily available for analysis and the trees sampled did not show a comparable number of GD here. In total, four different spatial patterns of overbank sedimentation events with characteristic breakout locations were reconstructed. Table 2 gives an overview on the sedimentation patterns (i.e. A to D) for the 15 events, while the position of trees showing GD during three particular incidences is given in Fig. (6).

Table 2. Overview of the Different Years and Types of Debris Flows that have Caused Overbank Sedimentation on the Cone of the Illgraben Torrent Between 1793 and 2007. For Explanations and More Details See Fig. (6) and Main Text

\begin{tabular}{|c|c|}
\hline Event & Flow Pattern \\
\hline \hline 1793 & D \\
\hline 1843 & A \\
\hline 1854 & D \\
\hline 1883 & D \\
\hline 1892 & A \\
\hline 1907 & A \\
\hline 1932 & A \\
\hline 1947 & B \\
\hline 1951 & A \\
\hline 1953 & A \\
\hline 1955 & A \\
\hline 1957 & A \\
\hline 1987 & C \\
\hline 1993 & C \\
\hline 2005 & C \\
\hline & \\
\hline & \\
\hline
\end{tabular}

Pattern A is represented with a debris-flow event dated to 1892 (Fig. 6A). During this type of overbank sedimentation, surges leave the canyon at two different locations: While part of the material apparently breaks out of the current canyon at $\sim 770 \mathrm{~m}$ a.s.l., part of the event remains in the current channel and only affects the western part of the cone at approximately $\sim 720 \mathrm{~m}$ a.s.l., where it uses the currently abandoned channel. Despite the primarily muddy and slurry composition of debris flows, it can be seen from Fig. (6A) that more than 120 trees show obvious GD resulting from the passing material. As illustrated in Table 2, pattern A appar- ently represents the most common outbreak model and can be observed for more than half of the events.

The debris flow of 1947 illustrates outbreak pattern B and is illustrated in Fig. (6B). During this type of overbank sedimentation event, damage is observed in trees located in the central part of the cone (between 720 and $660 \mathrm{~m}$ a.s.1.), but not at the upper breakout location as described for pattern A. Trees located in the currently abandoned channel show signs of GD during this type of event as well and a total of 104 trees helped the identification of the 1947 debris flow. It also seems that surges bifurcated at $720 \mathrm{~m}$ a.s.l. and that they used both the present-day and the currently abandoned canyon during the 1947 event. It is also worthwhile to note that the 1947 event seems to be the only event that affected only the lower but not the upper western part of the cone.

Pattern C is illustrated in Fig. (6C) with the debris-flow event of 1987. During this particular type of event, the cone remains unaffected and GD in trees are exclusively observed in trees growing on the lower terraces inside the channel. Events of type C are all recent and occurred in 1987, 1993 and 2005.

The fourth type of overbank sedimentation event, pattern $\mathrm{D}$, was reconstructed for the event years 1793, 1854 and 1883. During these events, which are not illustrated in Fig. (6), only trees located close to the upper breakout zone at $\sim 770 \mathrm{~m}$ a.s.l. show GD. In contrast, signs of disturbance are neither observed at the lower breakout location at $\sim 720 \mathrm{~m}$ a.s.l. nor in the upper parts of the currently abandoned channel, which is partly due to the limited age of sampled trees here.

\section{DISCUSSION}

In the study we report here, dendrogeomorphological analyses of 451 Pinus sylvestris L., 37 Larix decidua Mill. and 5 Picea abies (L.) Karst. trees have been used to identify outbreak locations and overbank sedimentation events on the cone of the Illgraben torrent in the Rhone valley (Valais, Switzerland). In total, the study of the tree-ring records allowed reconstruction of the overbank sedimentation of 15 events for the period AD 1793-2007.

The debris-flow frequency presented in this study gives the minimum number of overbank sedimentation events that occurred in this torrent in the recent past. The study also shows that there are possibilities to date fine-grained debrisflow surges with tree-ring records from drought-sensitive $P$. sylvestris trees. At the same time, we also have to admit that the number of reconstructed events is small as compared to the large number of growth disturbances (GD) observed on the increment cores (2363 GD). It appears that the finegrained calcareous and dolomitic material transported by the rather liquid debris flows not only leads to a scarcity of clearly visible geomorphic forms on the surface of the cone, but also to a scarcity of clear GD left by larger calcite and quartzite boulders transported by the debris-flow body (such as scars or decapitation).

In a similar way, we also realize that stem burial with subsequent growth suppression does necessarily seem to be a major problem for all $P$. sylvestris trees at the study site. In 


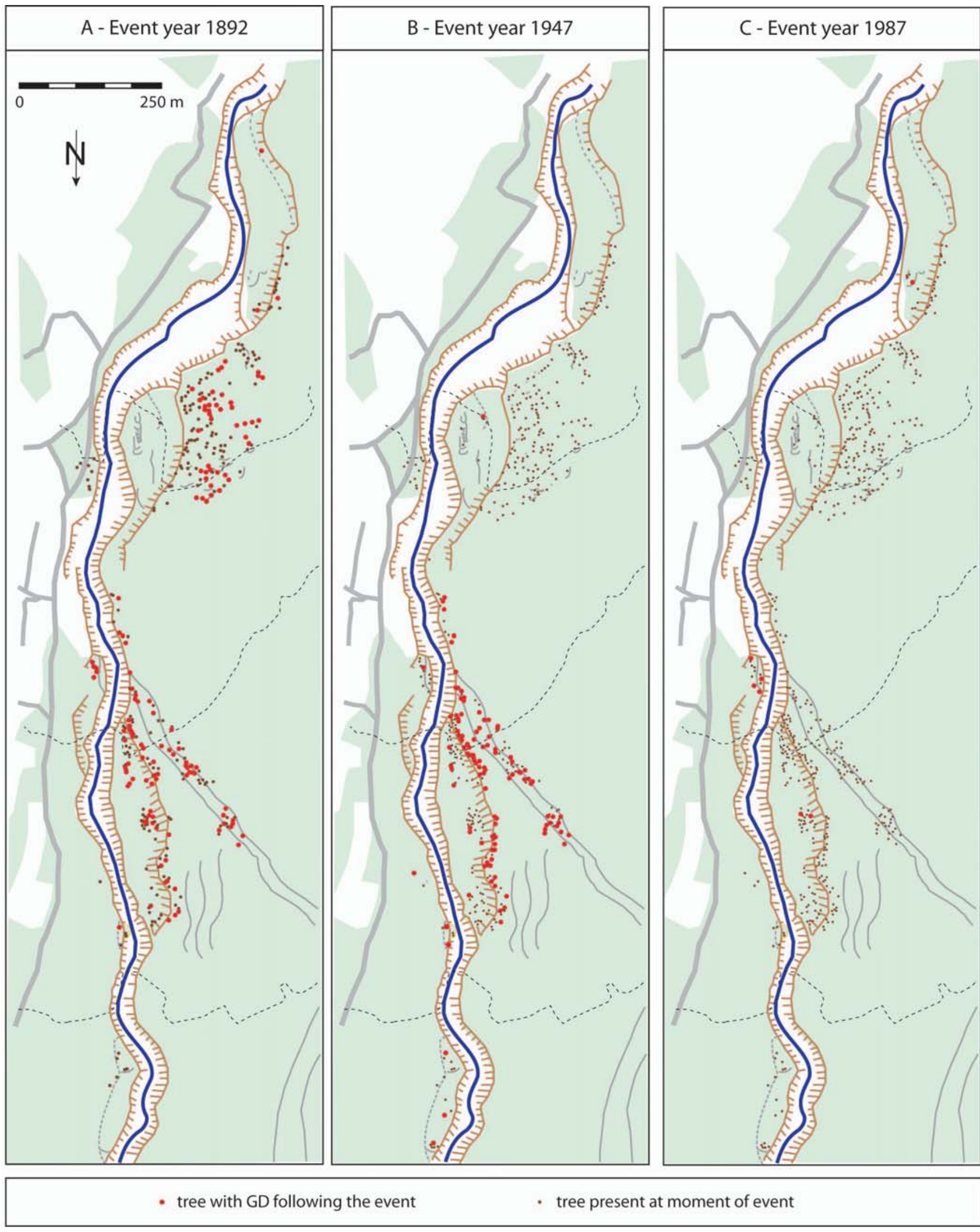

Fig. (6). Outbreak locations and specific spatial patterns of overbank sedimentation on the Illgraben cone during selected events: (A) In 1892, outbreaks from the channel occurred at 770 and $720 \mathrm{~m}$ a.s.1., affecting more than 120 trees on the western part of the cone (pattern A); (B) During overbank sedimentation in 1947, trees located below $720 \mathrm{~m}$ a.s.l. were damaged by passing debris-flow material (pattern B); (C) After an incision of the canyon in the 1960s and stabilization works, debris flows nowadays only affect trees growing on the lower terraces inside the canyon, as in 1987 (pattern C). 
contrast, it seems as if the presence of water and the deposition of calcareous material by individual events would sometimes act as a fertilizer to this poor and carbonate rich soils and that $P$. sylvestris trees would manage to compensate the negative effect of slight burial with the additional nutrient supply.

Clear signs of growth suppression are, in contrast, visible when trees were heavily buried, decapitated or important parts of their roots exposed [10]. In both cases, P. sylvestris reacted with suppressed growth to this kind of disturbance. However and as precipitation only totals $\sim 570 \mathrm{~mm} \mathrm{yr}^{-1}$ on the Illgraben cone [26], sudden growth suppression may also be the result of water stress and related droughts, leaving signs comparable to those observed after geomorphic process activity.

Besides the fact that the reconstruction of debris-flow events was hampered by the scarcity of large calcite and quartzite boulders leaving only a small number of clearly visible scars, the presence of droughts made it, in addition, impossible to date past debris-flow events based on the analysis of growth suppression alone. We therefore analyzed precipitation records of the last 143 years (1864-2007) from nearby weather stations (i.e. Sion and Sierre, located 5 and $21 \mathrm{~km}$ west of the study site, respectively) of the Swiss Meteorological Institute [26] and results from dendroecological studies $[23,24,36]$ in order to exclude the influence of water stress and related droughts on the dendrogeomorphological reconstruction. In two cases and due to the fact that GD did not only occur in the form of abrupt growth suppression but also as injuries and compression wood, debris-flow events were dated although the years in question were known for their droughts.

Debris flows are very common at Illgraben and 24 events have been reported since the beginning of systematic observation of the torrent in 2000 and until October 2006 [34]. A large majority of these events does not leave the actual channel and, based on our reconstructions, it seems that debris flows only very exceptionally left the canyon over the last 200 years. This is why the number of reconstructed events might appear quite small as compared to other torrents analyzed with tree-ring analyses in the Valais Alps [17-22]. Since the beginning of the systematic debris-flow observation in the Illgraben torrent in the year 2000 [32, 33], only one of the 2005 events has apparently affected trees located on a terrace at $\sim 780 \mathrm{~m}$ a.s.l. Events comparable to the one in 2005 are observed for 1993 and 1987, but not for the rest of the $20^{\text {th }}$ century or even the time before.

It is also obvious from the reconstruction that debris-flow surges did not leave the canyon and affect trees located on the cone itself since the 1950 s, when several debris flows left GD in trees located on its western part in 1951, 1953, 1955 and 1957. This is also the moment of last activity in the currently abandoned channel which is bifurcating from the present-day canyon at $\sim 720 \mathrm{~m}$ a.s.1.

Outbreaks from the current canyon and overbank sedimentation at Illgraben are only possible under certain conditions: either, (i) one or several large debris-flow surges are deposited in the canyon having a mean slope gradient of only $10.2^{\circ}$, blocking the channel at critical locations or lifting up the channel bed, thus reducing the depth of the canyon; or (ii) passing debris-flow surges destabilize the lateral walls of the canyon, thus leading to landslides that could theoretically block the canyon as well; or (iii) large debris-flow events transporting volumes of at least $250^{\prime} 000$ to $500^{\prime} 000 \mathrm{~m}^{3}$ would break out at the before-mentioned locations and lead to overbank sedimentation on the cone.

Such very large events are noted for the early 1960s, when a rockslide in March 1961 provided large amounts of erodible material for debris flows [25, 31]. Although this period of activity probably produced the largest surges of at least - the $20^{\text {th }}$ century, we do not identify signs of debris flows in the trees located on the western part of the cone. We therefore believe that the large debris-flow events that occurred following the March 1961 rockslide would have lead to an important channel incision rather than resulting in overbank sedimentation events on the cone. This assumption is supported by the fact that none of the large events did apparently cause (major) damage to the settlements of Susten and Pletschen (Fig. 1) or to the agricultural land on the eastern part of the cone [25].

The channel has apparently remained incised since the 1960s, rendering outbreaks as illustrated for older events in Fig. $(\mathbf{6 A}, \mathbf{B})$ very improbable under current conditions. In addition, various channel stabilization measures realized in the late 1960s [31] have further helped to prevent the occurrence of very large debris flows departing from the upper catchment and excessive channel bed modifications and related channel wall collapses on the cone.

Vertical changes in the channel bed along with stabilization measures appear to be the reason for the absence of debris flows on the cone since the late 1950s. A quantitative assessment of the changes in canyon depth would be very helpful for the understanding of debris-flow dynamics on the Illgraben cone. Unfortunately, topographic maps available for the site do not provide a sufficient degree of detail for the analysis of vertical changes in the channel geometry and the quality of aerial photographs (i.e. reduced contrast between the channel and terraces) is not good enough for a reliable study of changes since the 1950 s either. In contrast, it is possible to investigate changes in the width of the Illgraben canyon based on different generations of topographic maps and aerial photographs. Here, it appears that the position of the canyon has apparently remained stable for at least the last 170 years and that the channel bed would have migrated inside the canyon [47].

It therefore seems that understanding of (sub-)recent debris-flow dynamics at Illgraben could mainly be improved through the study of events leading to lateral erosion and collapses of the canyon walls as well as through the analysis of channel bed migration events inside the canyon. Even if the different terraces and islands inside the canyon are not populated with century-old conifer trees, the analysis of scars visible in the predominantly young broadleaved trees would certainly help the understanding of the channel evolution and channel migration inside the Illgraben canyon for at least some of the time since the large and vegetationremoving events in the 1960s.

\section{CONCLUSION}

The dendrogeomorphological analysis of 1004 increment cores extracted from Pinus sylvestris L., Larix decidua Mill. 
and Picea abies (L.) Karst. trees allowed accurate dating of 15 previous overbank sedimentation events and their spatial extent on the cone of the Illgraben torrent. P. sylvestris has proved to be useful for tree-ring reconstructions of debrisflow events, although the species has some limitations due to its sensitivity to droughts. Based on the results, we also conclude that overbank sedimentation events are not very realistic under current conditions and that they could only occur if major geomorphic changes would occur in the main canyon on the cone (channel filling, collapse of lateral walls). More research is needed on growth reactions of $P$. sylvestris to geomorphic events and the fertilizing effect of fine-grained, calcareous debris-flow deposits on tree growth as well as on tree-ring signals in broadleaved trees following debris-flow events.

\section{ACKNOWLEDGEMENTS}

The authors offer sincere thanks to Alexandre Badoux, Christoph Graf and Brian McArdell from the Swiss Federal Research Institute WSL for valuable discussions and data on debris flows at Illgraben. They also acknowledge Angela Heule for assistance in the field. We are also indebted to Service des Forêts et du Paysage (SFP) and the Service des Routes et des Cours d'Eau (SRCE), Canton of Valais, for financial support of this study being part of the RUFINE project.

\section{REFERENCES}

[1] W. Bloetzer, T. Egli, A. Petrascheck, J. Sauter, and M. Stoffel, "Klimaänderungen und Naturgefahren in der Raumplanung. Synthesebericht NFP31, "vdf Hochschulverlag AG: Zürich, 1998.

[2] M. Jakob, O. Hungr, Ed, "Debris-flow hazards and related phenomena”, Berlin; Heidelberg; New York: Springer, 2005.

[3] A. Carrara, F. Guzzetti, M. Cardinali, P. Reichenbach, "Use of GIS Technology in the Prediction and Monitoring of Landslide Hazard," Nat. Hazards., vol. 20, pp. 117-135, Nov 1999.

[4] M. Cardinali, P. Reichenbach, F. Guzzetti et al., "A geomorphological approach to the estimation of landslide hazards and risks in Umbria, Central Italy," Nat. Hazard. Earth. Syst. Sci., vol. 2, pp. 57-72, 2002

[5] A. Pasuto, M. Soldati, "An integrated approach for hazard assessment and mitigation of debris flows in the Italian Dolomites," Geomorphology, vol. 61, pp. 59-70, July 2004.

[6] D. Rickenmann, M. Zimmermann, "The 1987 debris flows in Switzerland: documentation and analysis," Geomorphology, vol. 8, pp. 175-189, Nov 1993.

[7] M. Zimmermann, P. Mani, H. Romang, "Magnitude-frequency aspects of alpine debris flows," Eclogae. Geol. Helv., vol. 90(3), pp. 415-420, 1997.

[8] BWG, Hochwasser 2000 - Les crues 2000. Bundesamt für Wasser und Geologie: Bern, 2002

[9] G. R. Bezzola, C. Hegg, Ed., Ereignisanalyse Hochwasser 2005. Teil 1 - Prozesse, Schäden und erste Einordnung, Bern; Birmensdorf: Bundesamt für Umwelt, Eidgenössische Forschungsanstalt WSL, 2007

[10] M. Stoffel, M. Bollschweiler, "Tree-ring analysis in natural hazards research - an overview," Nat Hazard Earth Syst Sci, vol. 8, pp. 187-202, March 2008

[11] J. Alestalo, "Dendrochronological interpretation of geomorphic processes,“Fennia, vol. 105, pp. 1-140, 1971

[12] J. F. Shroder, "Dendrogeomorphology: review and new techniques of tree-ring dating," Prog. Phys. Geogr., vol. 4, pp. 161-188, June 1980.

[13] D. R. Butler, "Teaching general principles and applications of dendrogeomorphology," J. Geol. Educ., vol. 35, pp. 64-70, 1987.

[14] F. H. Schweingruber, "Tree Rings and Environment. Dendroecology “, Paul Haupt Verlag. Bern, Stuttgart, Wien, 1996.

[15] H. Strunk, "Dating of geomorphological processes using dendrogeomorphological methods," Catena, vol. 31, pp. 137-151, Nov 1997.
[16] C. L. May, R. E. Gresswell, "Spatial and temporal patterns of debris-flow deposition in the Oregon Coast Range, USA," Geomorphology, vol. 57, pp. 135-149, Feb 2004.

[17] M. Bollschweiler, M. Stoffel, "Debris flows on forested cones reconstruction and comparison of frequencies in two catchments in Val Ferret, Switzerland," Nat. Hazard. Earth. Syst. Sci., vol. 7, pp. 207-218, March 2007

[18] M. Bollschweiler, M. Stoffel, M. Ehmisch, M. Monbaron, "Reconstructing spatio-temporal patterns of debris-flow activity with dendrogeomorphological methods," Geomorphology, vol. 87(4), pp. 337-351, July 2007.

[19] M. Stoffel, D. Conus, M. A. Grichting, I. Lièvre, G. Maître "Unraveling the patterns of late Holocene debris-flow activity on a cone in the Swiss Alps: chronology, environment and implications for the future," Global. Planet. Change, vol. 60, pp. 222-234, Feb 2008

[20] M. Bollschweiler, M. Stoffel, D. M. Schneuwly, "Dynamics in debris-flow activity on a forested cone - a case study using different dendroecological approaches," Catena, vol. 72(1), pp. 67-78, Jan 2008.

[21] M. Stoffel, I. Lièvre, D. Conus et al., "400 years of debris flow activity and triggering weather conditions: Ritigraben, Valais, Switzerland," Arct. Antarc. Alp. Res., vol. 37, pp. 387-395, 2005.

[22] M. Stoffel, M. Beniston, "On the incidence of debris flows from the early Little Ice Age to a future greenhouse climate: a case study from the Swiss Alps," Geophys. Res. Lett., vol. 33, L16404, Aug 2006.

[23] A. Rigling, O. U. Bräker, G. Schneiter, F. H. Schweingruber, "Intra-annual tree-ring parameters indicating differences in drought stress of Pinus sylvestris forests within the Erico-Pinion in the Valais (Switzerland)," Plant Ecol., vol. 163, pp. 105-121, Nov 2002.

[24] A. Rigling, H. Brülhardt, O. U. Bräker, T. Forster, F. H. Schweingruber, "Irrigation effect on tree growth and vertical resin duct production of Pinus sylvestris L. on dry sites in the Central Alps, Switzerland," For. Ecol. Manage., vol. 175, pp. 285-296, March 2003.

[25] Geo7, Geomorphologische Analyse des Illgrabens, Unpublished technical report. Geo7: Bern, 2000.

[26] SMI, 2008. Precipitation records of the Swiss Meteorological Institute weather stations Sierre and Sion. http://www.meteoschweiz. admin.ch/web/en/weather.html (site accessed 31 March 2008).

[27] BUWAL, Hydrologisches Jahrbuch der Schweiz 1999. Bundesamt für Umwelt: Bern, 1999

[28] M. Schürch, F. D. Vuataz, "Groundwater components in the alluvial aquifer of the alpine Rhone River valley, Bois de Finges area, Wallis Canton, Switzerland," Hydrogeol. J., vol. 8, pp. 549-563, Oct 2000.

[29] P. Werner, "La végétation de finges et de son Rhône sauvage," Bull. Murith., vol. 103, pp. 39-84, 1985.

[30] T. P. Labhart, 2004. Geologie der Schweiz, 6 ${ }^{\text {th }}$ edn; Ott Verlag: Thun.

[31] C. Lichtenhahn, Zwei Betonmauern: Die Geschieberückhaltsperre am Illgraben (Wallis). International Symposium Interpraevent, pp. 451-456, 1971

[32] M. Hürlimann, D. Rickenmann, C. Graf, "Field and monitoring data of debris flow events in the Swiss Alps," Can. Geotech. J, vol. 40, pp. 161-175, Jan 2003.

[33] B. W. McArdell, P. Bartelt, J. Kowalski, "Field observations of basal forces and fluid pore pressure in a debris flow," Geophys. Res. Lett., vol. 34, L07406, April 2007.

[34] T\&C, WSL, ,Technischer Bericht Notfallkonzept Illgraben. PROGE Notfallkonzept Illgraben,“ T\&C and WSL: Visp and Birmensdorf, 2005.

[35] Rinntech. 2008. LINTAB - precision ring by ring. http://www. rinntech.com/Products/Lintab.htm (site accessed 31 March 2008)

[36] B. Eilmann, P. Weber, A. Rigling, D. Eckstein, "The influence of drought on the wood structure of Pinus sylvestris L. and Quercus pubescens Willd. in Valais, Switzerland," Dendrochronologia, vol. 23, pp. 121-132, Feb 2006.

[37] E. R. Cook, L. A. Kairiukstis, Methods of dendrochronology applications in the environmental sciences, Kluwer: London, 1990. F. H. Schweingruber, Dendroökologische Holzanatomie, Paul Haupt Verlag: Bern, Stuttgart, Wien, 2001.

[39] J. R. McAuliffe, L. A. Scuderi, L. D. McFadden, "Tree-ring record of hillslope erosion and valley floor dynamics: landscape responses to climate variation during the last $400 \mathrm{yr}$ in the Colorado Plateau, 
northeastern Arizona," Glob. Planet. Change, vol. 50(3-4), pp. 184-201, April 2006.

[40] R. R. Braam, E. E. J. Weiss, P. A. Burrough, "Spatial and temporal analysis of mass movement using dendrochronology," Catena, vol. 14, pp. 573-584, Dec 1987.

[41] R. Fantucci, M. Sorriso-Valvo, "Dendrogeomorphological analysis of a slope near Lago, Calabria (Italy)," Geomorphology, vol. 30, pp. 165-174, Oct 1999.

[42] M. Stoffel, D. Schneuwly, M. Bollschweiler et al., "Analyzing rockfall activity (1600-2002) in a protection forest - a case study using dendrogeomorphology," Geomorphology, vol. 68, pp. 224241, June 2005 .
[43] D. M. Schneuwly, M. Stoffel, "Changes in spatio-temporal patterns of rockfall activity on a forested slope - a case study using dendrogeomorphology," Geomorphology, in press.

[44] D. M. Schneuwly, M. Stoffel, "Tree-ring based reconstruction of the seasonal timing, major events and origin of rockfall on a casestudy slope in the Swiss Alps," Nat. Hazard. Earth. Syst. Sci., vol. 8, 203-211, March 2008.

[45] M. W. Bannan, "Vertical resin ducts in the secondary wood of the Abietineae," New. Phytol., vol. 35, pp. 11-46, 1936.

[46] M. Stoffel, "Dating past geomorphic processes with tangential rows of traumatic resin ducts," Dendrochronologia, in press.

[47] P. Aeby, "Umwandlung von Luftbildern des Illgrabens VS in Orthophotos," Remote Sensing Thesis, University of Fribourg, Fribourg, Switzerland, 2007.

(C) Stoffel et al.; Licensee Bentham Open.

This is an open access article distributed under the terms of the Creative Commons Attribution License (http://creativecommons.org/licenses/by/2.5/), which permits unrestrictive use, distribution, and reproduction in any medium, provided the original work is properly cited. 